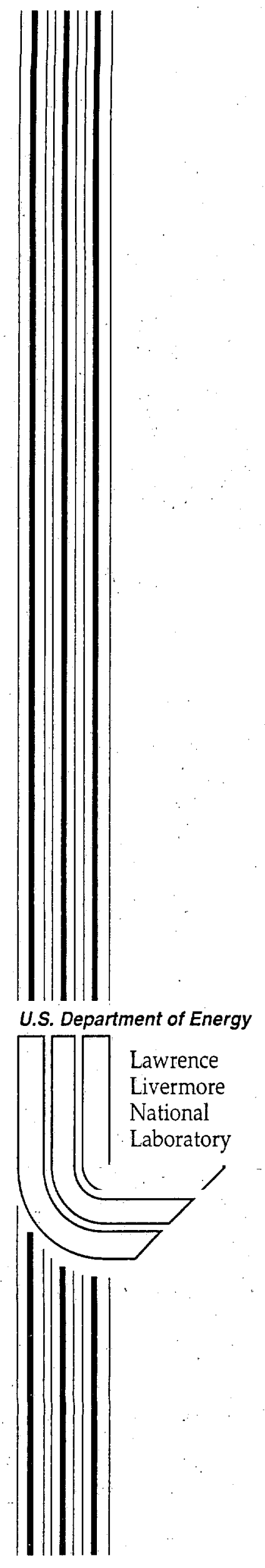

\title{
Chemical Kinetics of Hydrocarbon Ignition in Practical Combustion Systems
}

C.K. Westbrook

This article was submitted to $28^{\text {th }}$ International Symposium on Combustion, Edinburgh, Scotland, July 30 - August 4, 2000

\section{July 7, 2000}




\title{
Chemical Kinetics of Hydrocarbon Ignition in Practical Combustion Systems
}

\author{
Charles K. Westbrook \\ Lawrence Livermore National Laboratory, Livermore, CA 94550 USA
}

\begin{abstract}
Chemical kinetic factors of hydrocarbon oxidation are examined in a variety of ignition problems. Ignition is related to the presence of a dominant chain branching reaction mechanism that can drive a chemical system to completion in a very short period of time. Ignition in laboratory environments is studied for problems including shock tubes and rapid compression machines. Modeling of the laboratory systems are used to develop kinetic models that can be used to analyze ignition in practical systems. Two major chain branching regimes are identified, one consisting of high temperature ignition with a chain branching reaction mechanism based on the reaction between atomic hydrogen with molecular oxygen, and the second based on an intermediate temperature thermal decomposition of hydrogen peroxide. Kinetic models are then used to describe ignition in practical combustion environments, including detonations and pulse combustors for high temperature ignition, and engine knock and diesel ignition for intermediate temperature ignition. The final example of ignition in a practical environment is homogeneous charge, compression ignition (HCCI) which is shown to be a problem dominated by the kinetics of intermediate temperature hydrocarbon ignition. Model results show why high hydrocarbon and $\mathrm{CO}$ emissions are inevitable in $\mathrm{HCCI}$ combustion. The conclusion of this study is that the kinetics of hydrocarbon ignition are actually quite simple, since only one or two elementary reactions are dominant. However, there are many combustion factors that can influence these two major reactions, and these are the features that vary from one practical system to another.
\end{abstract}




\section{Introduction}

In many practical steady combustion systems, ignition is simply a means of starting the system on its way to steady state. Performance and emissions are essentially independent of ignition in such systems as boilers, furnaces and burners. However, in other practical problems, ignition has a great influence on performance, emissions and other characteristics, and ignition can explain the performance of the entire system.

Ignition can depend on physical, chemical, and mixing and transport features of a problem, and in some cases on heterogeneous phenomena. Excellent reviews of ignition can be found in current sources [1-4], describing thermal feedback, chemical kinetic chain branching reactions, and other elements. However, ignition in general is an enormous subject, and the present work cannot provide a thorough treatment.

This paper focuses on chemical kinetic factors in practical systems, with special attention on ignition in automotive engines. Recent advances in experimental and kinetic modeling capabilities have provided new insights into ignition, offering new possibilities for control strategies and new classes of combustors.

\section{General Features of Ignition}

Many interesting systems involve chain reactions, such as nuclear reactors, with neutrons as chain carriers. Chain termination is provided by neutron absorbers, and chain branching is associated with the term "supercritical", normally a condition to be avoided. Populations of living organisms obey the same reactivity laws. Organisms can grow exponentially via 
chain branching until limited availability of nutrients first stabilizes the population and eventually quenches the system via chain termination.

Reacting systems follow the general equation

$$
\frac{d}{d t}(t)=k n(t)
$$

where $n(t)$ is the number of chain carriers. This indicates that the change in number of neutrons in a reactor depends on the number of neutrons available to produce further neutrons, or the change in the number of bacteria depends on the number of bacteria which can reproduce, a reflection that the current population of chain carriers produces the next generation of chain carriers.

Solution of equation (1) leads to the expression

$$
n(t)=n(0) \exp (k t)
$$

When $\mathrm{k}<0$, the result is exponential decay; when $\mathrm{k}>0$ the radical population experiences exponential growth. Thus $k \cong 0$ is equivalent to criticality or steady combustion (or population stability). In a chemically reactive system, the coefficient $\mathrm{k}$ is an average over all reactions taking place, including initiation, termination, propagation and branching reactions. We can define ignition by requiring that the reacting system must experience exponential growth both in temperature and number of chain carriers, and the exponential chain reaction must proceed for a significant degree of fuel consumption. 


\section{Chain reactions}

Early analyses $[5,6]$ established the chain character of reaction of the $\mathrm{H}_{2}-\mathrm{O}_{2}$ system, and the same principles apply to hydrocarbon oxidation. Chain

carriers are radical species such as $\mathrm{H}$ and $\mathrm{O}$ atoms, and $\mathrm{OH}, \mathrm{CH}_{3}, \mathrm{HO}_{2}$, and it is usually straightforward to identify reactions as initiation, propagation, branching, and termination.

Initiation reactions generate radicals from stable species, such as the decomposition of propane:

$$
\mathrm{C}_{3} \mathrm{H}_{8} \rightarrow \mathrm{CH}_{3}+\mathrm{C}_{2} \mathrm{H}_{5}
$$

Chain propagation reactions maintain the number of radical species, as in:

$$
\mathrm{C}_{2} \mathrm{H}_{6}+\mathrm{OH} \rightarrow \mathrm{C}_{2} \mathrm{H}_{5}+\mathrm{H}_{2} \mathrm{O}
$$

consuming $\mathrm{OH}$ and producing ethyl radicals. Chain termination reduces the number of radicals, as in recombination producing stable butane:

$$
\mathrm{C}_{2} \mathrm{H}_{5}+\mathrm{C}_{2} \mathrm{H}_{5} \rightarrow \mathrm{C}_{4} \mathrm{H}_{10}
$$

The key to understanding ignition kinetics is to identify the chain branching steps under conditions being studied. In chain branching reactions, the number of radicals increases, as in:

$$
\mathrm{CH}_{4}+\mathrm{O} \rightarrow \mathrm{CH}_{3}+\mathrm{OH}
$$

consuming one $\mathrm{O}$ atom and producing two radicals. The most important high temperature chain branching reaction consumes one $\mathrm{H}$ atom and produces two radicals, $\mathrm{O}$ and $\mathrm{OH}$ : 


$$
\mathrm{H}+\mathrm{O}_{2} \rightarrow \mathrm{O}+\mathrm{OH}
$$

These illustrations are encapsulated into single reactions. However, it is common to find situations where chain properties are best attributed to a sequence of reactions. For example, an important reaction sequence is

$$
\begin{aligned}
& \mathrm{C}_{3} \mathrm{H}_{8}+\mathrm{HO}_{2} \rightarrow \mathrm{C}_{3} \mathrm{H}_{7}+\mathrm{H}_{2} \mathrm{O}_{2} \\
& \mathrm{H}_{2} \mathrm{O}_{2} \rightarrow \mathrm{OH}+\mathrm{OH}
\end{aligned}
$$

consuming one hydroperoxy radical and producing three radicals, a propyl radical and two hydroxyl radicals. In some situations, the sequence of reactions can be much longer before its chain properties become evident.

Finally, not all radical species have the same influence on the overall reaction rate, due to subsequent reactions with different branching characteristics. For example, at high temperatures, where reaction (7) is the major chain branching step, production of ethyl radicals accelerates the overall rate of ignition because $\mathrm{C}_{2} \mathrm{H}_{5}$ produces $\mathrm{H}$ atoms which then provide

$$
\mathrm{C}_{2} \mathrm{H}_{5} \rightarrow \mathrm{C}_{2} \mathrm{H}_{4}+\mathrm{H}
$$

chain branching via reaction (7), while production of methyl radicals actually decreases or inhibits the overall rate of ignition at high temperatures because methyl radicals recombine, resulting in chain termination:

$$
\mathrm{CH}_{3}+\mathrm{CH}_{3} \rightarrow \mathrm{C}_{2} \mathrm{H}_{6}
$$

The specific reaction sequences that provide chain branching change as the temperature, pressure and reactant composition change. In discussions below, chemical kinetic factors for ignition under a variety of conditions will be 
examined, and for each environment, the essential task will be to identify the chemical kinetic reaction sequences that lead to chain branching.

High temperature ignition, shock tubes, detonations and pulse combustors At temperatures above about $1200 \mathrm{~K}$, the dominant chain branching step.in hydrocarbon ignition is reaction (7) [7-12], with $\mathrm{H}$ atoms that are produced by thermal decomposition of radicals such as ethyl, vinyl, formyl, isopropyl and others. Activation energies of these reactions are quite large (e.g., $30 \mathrm{kcal} / \mathrm{mol}$ ) and the activation energy of reaction (7) is also quite large $(16.8 \mathrm{kcal} / \mathrm{mol})$, so these reactions need high temperatures to proceed.

\section{Shock Tubes}

High temperature $(\mathrm{T} \geq 1200 \mathrm{~K})$ shock tube ignition is controlled by reaction (7). At shock tube temperatures, there is an initiation period for radical generation, followed by a period of explosive, exponential growth in radicals, dominated by reaction (7), consuming fuel and increasing the temperature. An. interesting series of experiments was reported by Burcat et al. [13] for ignition of stoichiometric mixtures of n-alkanes in oxygen/argon. Fuels included methane, ethane, propane, $n$-butane and n-pentane. Measured ignition delay times are summarized as symbols in Figure 1, together with computed values using kinetic reaction mechanisms, with the exception of ethane; the heavy dashed line is a fit to the experimental results for ethane ignition, and no computed results for ethane are presented in Fig. 1. Calculated results for iso-butane are indicated as a dotted line and are virtually indistinguishable from n-butane and n-pentane. Of these five n-alkane fuels, methane ignites slowest, ethane most rapidly, and 
the three higher $\mathrm{n}$-alkanes have intermediate reactivity and are very similar to each other. Kinetic modeling shows that methane ignites slowest because methyl radicals, resulting from $\mathrm{H}$ atom abstraction from methane, lead to chain termination through reaction (11). Ethane is most reactive because every ethyl radical, resulting from $\mathrm{H}$ atom abstraction from ethane, produces an $\mathrm{H}$ atom via reaction (10). For higher n-alkanes, twọ or more alkyl radicals are produced, some of which produce $\mathrm{H}$ atoms and chain branching through reaction (7), and some produce methyl radicals and chain termination through reaction (11). For example, butyl radicals from n-butane decompose:

$$
\begin{aligned}
& 1-\mathrm{C}_{4} \mathrm{H}_{9} \rightarrow \mathrm{C}_{2} \mathrm{H}_{4}+\mathrm{C}_{2} \mathrm{H}_{5} \\
& 2-\mathrm{C}_{4} \mathrm{H}_{9} \rightarrow \mathrm{C}_{3} \mathrm{H}_{6}+\mathrm{CH}_{3}
\end{aligned}
$$

Since reaction (10) produces $\mathrm{H}$ atoms from $\mathrm{C}_{2} \mathrm{H}_{5}$, these two steps show that n-butane produces a mixture of $\mathrm{H}$ atoms and $\mathrm{CH}_{3}$ radicals, and the same is true with propane and n-pentane. Thus methane and ethane represent extremes of reactivity, while larger alkane hydrocarbons have intermediate ignition properties due to their mixed production of $\mathrm{H}$ and $\mathrm{CH}_{3}$.

Sensitivity of the high temperature mechanism to reaction (7) is responsible for many practical phenomena. Flame and detonation inhibitors catalyze removal of $\mathrm{H}$ atoms [14-19], as illustrated here in the case of $\mathrm{HBr}$ :

$$
\begin{aligned}
& \mathrm{H}+\mathrm{HBr} \rightarrow \mathrm{H}_{2}+\mathrm{Br} \\
& \mathrm{H}+\mathrm{Br}_{2} \rightarrow \mathrm{HBr}+\mathrm{Br} \\
& \mathrm{Br}+\mathrm{Br}+\mathrm{M} \rightarrow \mathrm{Br}_{2}+\mathrm{M}
\end{aligned}
$$


for a net reaction of:

$$
\mathrm{H}+\mathrm{H} \rightarrow \mathrm{H}_{2}
$$

This net removal of $\mathrm{H}$ atoms reduces the number of $\mathrm{H}$ atoms available for chain branching via reaction (7) and slowing the overall rate of ignition.

This discussion addresses the most common shock tube experiments. However, some shock tube experiments are carried out at lower temperatures (e.g., [20]) or at significantly elevated pressures (e.g., [21]), where the chain branching reaction sequences are different from the conventional high temperature conditions outlined here; these reaction environments will be discussed below:

\section{Detonations}

High temperature ignition kinetics and reaction (7) play essential roles in propagation of gaseous detonations, where post compression detonation temperatures and pressures are comparable with those in shock tubes. Although it is often convenient to consider a detonation as a planar phenomenon, detonations have a complex, three dimensional structure caused by interactions between transverse waves in the reactive medium [22,23]. The reactive shock wave decays during propagation and would fail if new ignition spots were not created by intersecting shock waves, or Mach stems. For this reason, detonation propagation depends very strongly on ignition kinetics. The result of these interactions is a cellular structure that can be measured using smoked foils in laboratory experiments. The widths of these detonation cells are fundamental 
features relating to the initiation, propagation and stability of gaseous detonations.

Because detonation structure is inherently three dimensional, and the reaction zone is spatially thin relative to cell sizes, computer models for detonations [24] have been unable to include full chemical submodels, although recent models [25], have used tabular look-up techniques to include finite-rate kinetics. Advances in massively parallel computer capabilities are likely to permit inclusion of detailed kinetics in future three dimensional CFD models of detonations.

Given computer costs of a 3D detonation model, the pseudo-onedimensional ZND model [26-28] has been used to relate computed ignition delay times to characteristic spatial and energy scales in a detonation. This approach calculates ignition delay times behind a CJ shock wave to define a characteristic length scale in the reacting gas mixture [29-37], which is then proportional to the cell width, critical tube diameter, minimum initiation energy and other detonation characteristics.

An exciting current development is extension of kinetic modeling to study detonations of condensed phase explosives [38-41], such as ammonium perchlorate, RDX or HMX. These models require treatment of three-dimensional fluid mechanics, multiphase phenomena and detailed chemical kinetics, and massively parallel computing is essential computational tool. Ignition kinetics in such an environment are complex, and a great deal of new research is needed. 


\section{Pulse combustion}

Pulse combustion has been known for centuries, but only recently have its physical and chemical principles become understood. Ignition and heating in the pulse combustor force exhaust gases out through an exhaust pipe; the resulting lower pressure in the combustion chamber then draws in fresh fuel and air. This fresh mixture combines with hot residual products of the previous burn, and the resulting fresh reactants and residual gases ignite, starting a new cycle. Because the average temperature is relatively low, production of $\mathrm{NO}_{\mathrm{x}}$ is also low.

Keller et al. [42-45] examined mixing, kinetics of ignition, and resonant acoustic wave propagation in the pulse combustor, showing that ignition must be timed to occur in phase with resonant pressure waves in the combustion chamber.

The kinetic submodel for this system mixes fresh fuel and air, initially at room temperature, with hot residual gases from the preceding cycle, steadily increasing the temperature of the fresh mixture as well as diluting it with the residual products. The overall reaction rate remains negligible until the mixture reaches temperatures about $1200 \mathrm{~K}$, where ignition is controlled by reaction (7). The kinetic model for this system predicts the influence of additives and variability in natural gas composition [46] to manipulate the kinetics of ignition, in a pulse combustor. This is a very rich system in terms of the parameters that can be adjusted to optimize the phasing between kinetic ignition and the resonant pressure wave in the combustion chamber. In addition to the kinetic parameters; the combustion chamber acoustic time scales can be modified, and the mixing rate can be varied by adjusting intake ports for fuel and air. 
Inteminediate temperature ignition, rapid compression machines, engine knock, diesel ignition and homogeneous charge compression ignition (HCCI)

At temperatures above about $850 \mathrm{~K}$ but below $1200 \mathrm{~K}$, reaction ( 7 ) is too slow to provide sufficient branching rates for ignition, and a different reaction path dominates. Key reactions include:

$$
\begin{aligned}
& \mathrm{H}+\mathrm{O}_{2}+\mathrm{M} \rightarrow \mathrm{HO}_{2}+\mathrm{M} \\
& \mathrm{RH}+\mathrm{HO}_{2} \rightarrow \mathrm{R}+\mathrm{H}_{2} \mathrm{O}_{2} \\
& \mathrm{H}_{2} \mathrm{O}_{2}+\mathrm{M} \rightarrow \mathrm{OH}+\mathrm{OH}+\mathrm{M}
\end{aligned}
$$

where $\mathrm{RH}$ is an alkane, $\mathrm{R}$ is an alkyl radical and $\mathrm{M}$ is a third body. Collectively, reactions (17-19) consume one $\mathrm{H}$ atom radical and produce two $\mathrm{OH}$ radicals, providing chain branching.

Kinetic studies in flow reactors and stirred reactors [47-49] at temperatures about $1000 \mathrm{~K}$ show that reactions (17-19) control combustion rates. In this range, reaction (19) is rapid, so $\mathrm{H}_{2} \mathrm{O}_{2}$ decomposes as rapidly as it is formed and $\mathrm{H}_{2} \mathrm{O}_{2}$ concentrations do not build up to appreciable levels. However, in many practical systems, the dominant feature of ignition is the accumulation of $\mathrm{H}_{2} \mathrm{O}_{2}$ until a temperature is reached where it decomposes to cause ignition. This is true in the laboratory rapid compression machine, and it is also the central kinetic feature in engine knock in spark ignition engines, ignition in liquid fueled diesel engines, and in the operation of homogeneous 
charge compression ignition ( $\mathrm{HCCI}$ ) engines. In each of these systems, $\mathrm{H}_{2} \mathrm{O}_{2}$

forms at lower temperatures and remains relatively inert, until increasing temperature from compression and exothermic reactions reaches a level where it decomposes rapidly via reaction (19). Each of these examples will be discussed below.

\section{Rapid compression machine}

Rapid compression machines (RCM) have been used for many years [5052] and provide a fertile environment for study of hydrocarbon oxidation. The apparatus provides a combustion chamber with a single piston stroke, leaving the compressed gases at temperatures from $550 \mathrm{~K}$ to $950 \mathrm{~K}$, depending on the compression ratio of the RCM and specific heats of reactant gases. Compressed gases can undergo a single-stage or two-stage ignition, or the reactants may not ignite at all while heat transfer cools the mixture to room temperature.

Typical results in Figure 2 are taken from numerical simulation of ignition of a stoichiometric mixture of neopentane and oxygen in $\mathrm{N}_{2}$ and $\mathrm{Ar}$ in proportions of $\mathrm{C}_{5} \mathrm{H}_{12} / \mathrm{O}_{2} / \mathrm{N}_{2} / \mathrm{Ar}=0.0256 / 0.2048 / 0.38 / 0.39$ at a postcompression temperature of $757 \mathrm{~K}$ [53]. In this example, the temperature history shows a well defined two-stage ignition, the first stage occurring after a delay of $5 \mathrm{msec}$, reaching a new temperature of about $880 \mathrm{~K}$. Temperature then remains relatively constant, rising slowly for the next $6-8 \mathrm{msec}$, then rising more rapidly until a total elapsed time of $14 \mathrm{msec}$, when the second stage ignition is observed and the temperature rises rapidly; consuming all of the fuel. In other cases, the 
first stage can occur during the compression stroke $[54,55]$ and is completed before the end of the compression, while in other cases there is no discernible first stage ignition.

The first stage ignition is a result of rather complex kinetic features of low temperature hydrocarbon oxidation [56]. This regime has considerable importance in theoretical and practical systems, and we will return to describe it in more detail below.

Figure 2 plots the concentrations of fuel, $\mathrm{H}_{2} \mathrm{O}_{2}$ and $\mathrm{OH}$. During the time preceding the second stage ignition, $\mathrm{H}_{2} \mathrm{O}_{2}$ concentration increases steadily. Until the temperature approaches $1000 \mathrm{~K}$, decomposition of $\mathrm{H}_{2} \mathrm{O}_{2}$ is much slower than its production, and the small amounts of $\mathrm{OH}$ that are produced are consumed by reactions with the fuel [57]. When a temperature close to $1000 \mathrm{~K}$ is reached, reaction (19) accelerates, $\mathrm{H}_{2} \mathrm{O}_{2}$ disappears and $\mathrm{OH}$ concentration increases rapidly. The increased $\mathrm{OH}$ concentrations rapidly consume any remaining fuel, followed by a rapid increase in temperature. Thus, decomposition of $\mathrm{H}_{2} \mathrm{O}_{2}$ and consumption of fuel result in ignition.

There is a critical temperature for ignition through $\mathrm{H}_{2} \mathrm{O}_{2}$ decomposition that is a function of the pressure of the reactive system. This is seen by examining the rate of $\mathrm{H}_{2} \mathrm{O}_{2}$ decomposition

$$
\frac{\mathrm{d}\left[\mathrm{H}_{2} \mathrm{O}_{2}\right]}{\mathrm{dt}}=-\left[\mathrm{H}_{2} \mathrm{O}_{2}\right][\mathrm{M}] \mathrm{k}
$$


where $\mathrm{M}$ is the total molar concentration. This equation can be rearranged into the form $\left[\mathrm{H}_{2} \mathrm{O}_{2}\right] /\left(\mathrm{d}\left[\mathrm{H}_{2} \mathrm{O}_{2}\right] / \mathrm{dt}\right)$, a characteristic decomposition time is

$$
\tau=\left[\mathrm{H}_{2} \mathrm{O}_{2}\right] /\left(\mathrm{d}\left[\mathrm{H}_{2} \mathrm{O}_{2}\right] / \mathrm{dt}\right)=1 /(\mathrm{k}[\mathrm{M}])
$$

With the rate constant for reaction (19), $\mathrm{k}_{19}=1.2 \times 10^{17}{ }^{*} \exp (-45500 / \mathrm{RT}), \tau$ becomes

$$
\tau=8.3 \times 10^{-18} * \exp (+22750 / \mathrm{T}) *[\mathrm{M}]^{-1}
$$

As temperature increases, $\tau$ becomes smaller, and when it is "short" compared to the residence time, ignition occurs. Characteristic decomposition time also decreases with increasing total concentration $[\mathrm{M}]$, or with increasing pressure at constant temperature. Therefore as pressure increases, the critical temperature for ignition decreases gradually.

Total post-compression concentrations in a representative RCM experiment are $1 \times 10^{-4} \mathrm{~mol} / \mathrm{cm}^{3}$, so $\tau$ is approximately $7.8 \mathrm{~ms}$ at $\mathrm{T}=900 \mathrm{~K}, 640 \mu \mathrm{s}$ at $\mathrm{T}=1000 \mathrm{~K}$ and $80 \mu$ s at $\mathrm{T}=1100 \mathrm{~K}$. With total reaction times of tens of milliseconds, rapid decomposition is observed at about $950-1000 \mathrm{~K}$, with characteristic times for ignition less than a millisecond. In studies of ignition at the higher pressures of internal combustion engines, including spark ignition, diesel and $\mathrm{HCCI}$ engines, the same calculation of equations 20-22 shows that this simple mechanism predicts ignition at temperatures between $900 \mathrm{~K}$ and $950 \mathrm{~K}$ [58]. Analysis of reaction (19) by Griffiths and Barnard [1] at its high pressure limit shows similar rates of decomposition at somewhat lower temperatures, consistent with the above trends as pressure increases. 
The key is that $\mathrm{H}_{2} \mathrm{O}_{2}$ decomposes rapidly at temperatures of $900-1000 \mathrm{~K}$, so this temperature can be considered as a critical value in systems where the temperature approaches this value from lower temperatures. $\mathrm{H}_{2} \mathrm{O}_{2}$ is produced at lower temperatures by low and intermediate temperature kinetic pathways, until the decomposition temperature is reached, when the system suddenly produces large numbers of $\mathrm{OH}$ radicals and rapidly ignites. The most important variable is the time at which they reach this critical temperature. Anything that will accelerate reaching this critical temperature advances its ignition, while delaying it inhibits ignition. The importance of the first stage, low temperature oxidation period, is that it provides heat release early in the reaction history, so the reactive mixture arrives at the decomposition temperature earlier than would have occurred without that early heat release.

\section{Low temperature chemical kinetics}

Low temperature hydrocarbon oxidation has been studied extensively [56]. Following abstraction of $\mathrm{H}$ atoms from the fuel, at high temperatures the alkyl radical $R$ decomposes, producing olefin and smaller alkyl radicals, and reaction (7) is the dominant chain branching reaction as discussed above. At lower temperatures, $\mathrm{O}_{2}$ adds to the alkyl:

$$
\mathrm{R}+\mathrm{O}_{2}+\mathrm{M} \rightarrow \mathrm{RO}_{2}+\mathrm{M}
$$

The equilibrium constant for reaction (23) is strongly temperature dependent and is strongly in favor of $\mathrm{RO}_{2}$ at low temperature, shifting toward $\mathrm{R}+\mathrm{O}_{2}$ as 
temperature increases. $\mathrm{RO}_{2}$ radicals isomerize to produce a $\mathrm{QOOH}$ radical species

$$
\mathrm{RO}_{2} \rightarrow \mathrm{QOOH}
$$

Isomerization depends sensitively on the size and structure of the original fuel molecule and the site in that fuel where the $\mathrm{O}_{2}$ group is located [56,58]. The $\mathrm{RO}_{2}$ will be produced with excess energy, so it is important to understand the rate of collisional stabilization, and whether subsequent reactions occur from the activated or ground state of $\mathrm{RO}_{2}$. The simplest example of such a system is the ethyl radical, with $\mathrm{RO}_{2}$ being the ethylperoxy radical $\mathrm{C}_{2} \mathrm{H}_{5} \mathrm{O}_{2}$ and $\mathrm{QOOH}$ being the hydroperoxyethyl radical $\mathrm{C}_{2} \mathrm{H}_{4} \mathrm{OOH}$. This system has been studied extensively [59-63], and even this small system is not fully understood. Bozzelli et al. $[64,65]$ examined the propyl $+\mathrm{O}_{2}$ system, but little experimental or theoretical work has been done for larger systems.

Several factors influence the rate of internal $\mathrm{H}$ atom transfer or radical isomerization. The species forms a ring-like transition state where the terminal $O$ atom approaches an extractable $\mathrm{H}$ atom within the $\mathrm{RO}_{2}$ species. The number of atoms in this transition state ring influences the rate of reaction, with 6- and 7-. membered rings having the most rapid rate. The type of $\mathrm{C}-\mathrm{H}$ bond broken has a strong influence, with primary $\mathrm{C}-\mathrm{H}$ bonds being strongest, secondary $\mathrm{C}-\mathrm{H}$. bonds next, and tertiary $\mathrm{C}-\mathrm{H}$ bonds being weakest. The rate and number of 
possible $\mathrm{RO}_{2}$ isomerization reactions increase with the fuel molecule size and are fastest in long, linear alkane fuel molecules, with a large number of 6- and 7membered transition state rings and a high percentage of easily abstracted secondary $\mathrm{C}-\mathrm{H}$ bonds, and are slowest in highly branched fuel molecules, with fewer low energy transition state rings and large percentages of difficult-toabstract primary $\mathrm{C}-\mathrm{H}$ bonds [58].

QOOH species react via several alternative paths which are formally chain propagation steps, beginning with one alkyl radical and produce one

$$
\begin{aligned}
& \mathrm{QOOH} \rightarrow \mathrm{Q}+\mathrm{HO}_{2} \\
& \mathrm{QOOH} \rightarrow \mathrm{QO}+\mathrm{OH}
\end{aligned}
$$

$\mathrm{HO}_{2}$ or $\mathrm{OH}$ radical, in addition to a stable olefin or cyclic ether. However, it is also possible for a second $\mathrm{O}_{2}$ molecule to add to $\mathrm{QOOH}$, creating a radical

$$
\mathrm{QOOH}+\mathrm{O}_{2} \rightarrow \mathrm{O}_{2} \mathrm{QOOH}
$$

$\mathrm{O}_{2} \mathrm{QOOH}$, which can then isomerize further, again with rates dependent on the structure and size of the original fuel molecule, as observed for $\mathrm{RO}_{2}$ isomerization. The isomerized product decomposes into a relatively stable ketohydroperoxide species and one $\mathrm{OH}$ radical. The ketohydroperoxide species then has its own temperature for decomposition at about $800 \mathrm{~K}$, somewhat lower than that of $\mathrm{H}_{2} \mathrm{O}_{2}$. Upon reaching this temperature, the ketohydroperoxide decomposes into several pieces, at least two of which are radicals. Thus, it is not until this final ketohydroperoxide decomposition step that chain branching is 
finally achieved in the low temperature oxidation regime. Since at least three of the ultimate products of this reaction sequence are radicals, chain branching is quite strong once the ketohydroperoxide decomposes. Production of metastable intermediates, ketohydroperoxide in this case and $\mathrm{H}_{2} \mathrm{O}_{2}$ earlier, followed later by the higher temperature decomposition of the metastable intermediate to finally provide chain branching, are examples of degenerate chain branching. Detailed low temperature reaction mechanisms have been developed [53$55,58,66,67]$ for a variety of hydrocarbon fuels.

This highly branched, low temperature oxidation phase continues until the temperature has increased enough that the equilibria in the molecular oxygen addition reactions (23) and (27) begin to shift towards dissociation. Because activation energies for dissociation are large (i.e., $\sim 35 \mathrm{kcal} / \mathrm{mol}$ ), the reactions shift rapidly towards dissociation as temperature increases. This shift with hydrocarbon fuels occurs at temperatures near $850 \mathrm{~K}$. The temperature above which these equilibria favor dissociation has been termed the "ceiling temperature" by Benson $[68,69]$.

The effect of fuel molecular structure on both the first and second stage ignition is illustrated in Figure 3, from Ribaucour et al. [53]. The three isomers of . pentane are compared at the same post-compression temperature of $757 \mathrm{~K}$. All three mixtures ignite at about 950K. N-pentane ignites first since its first stage occurs first and provides the largest temperature increase, neopentane $(2,2-$ dimethyl propane) ignites next and iso-pentane (2-methyl butane) is last, all because the time of occurrence and temperature increase of the first stage ignition vary in that order. All ignite when they reach the same critical 
temperature for $\mathrm{H}_{2} \mathrm{O}_{2}$ decomposition, and the differences between the isomers are the times when the fuel mixtures reach the critical temperature.

Total heat release in this low temperature regime is quite modest. In Figure 3, this varies from $50 \mathrm{~K}$ for 2 -methyl butane to $150 \mathrm{~K}$ for n-pentane. In engine studies, at TDC this difference makes a significant impact on ignition properties of the combustion system.

An interesting variation of this analysis simulates an RCM experiment in which an additive has been included in the neo-pentane fuel. This additive, ozone, has an initial concentration of $10 \mathrm{ppm}$ and decomposes early in the experimental cycle, since the activation energy for ozone decomposition is 24 $\mathrm{kcal} / \mathrm{mol}$, much less than the $45.5 \mathrm{kcal} / \mathrm{mol}$ for $\mathrm{H}_{2} \mathrm{O}_{2}$ decomposition. Repeating the analysis of equations $20-22$, the critical decomposition temperature for ozone at present conditions is about $600 \mathrm{~K}$. Computed results of this example are shown in Figure 4.

Decomposition of ozone at $5 \mathrm{~ms}$ before TDC (at $\sim 600 \mathrm{~K}$ ) produces $\mathrm{O}$ atoms. Each $\mathrm{O}$ atom consumes two fuel molecules

$$
\begin{aligned}
& \mathrm{O}_{3}+\mathrm{M} \rightarrow \mathrm{O}_{2}+\mathrm{O}+\mathrm{M} \\
& \mathrm{C}_{5} \mathrm{H}_{12}+\mathrm{O} \rightarrow \mathrm{C}_{5} \mathrm{H}_{11}+\mathrm{OH} \\
& \mathrm{C}_{5} \mathrm{H}_{12}+\mathrm{OH} \rightarrow \mathrm{C}_{5} \mathrm{H}_{11}+\mathrm{H}_{2} \mathrm{O}
\end{aligned}
$$

Pentyl radicals then proceed via reactions (23-27) and produce the metastable $C_{5}$

ketohydroperoxide species, the production of which is shown in Fig. 4, immediately following the decomposition of ozone. 
Ketohydroperoxide decomposition has an activation energy of about 42 $\mathrm{kcal} / \mathrm{mol}$, so it decomposes at about $800 \mathrm{~K}$, as seen in Fig. 4. Production of $\mathrm{OH}$ from decomposition produces further water and heat release: Decomposition of $\mathrm{H}_{2} \mathrm{O}_{2}$ and the ketohydroperoxide and the resulting heat release brings the reactive mixture to the first ignition stage before the conclusion of the compression stroke. Fig. 4 shows a slight inflection point at TDC, indicating that the low temperature ignition is well underway as the compression stroke ends. This phase stops at about $850 \mathrm{~K}$, the same temperature at which the first stage ended in the original mixture, without ozone (Figs. 2 and 3). Kinetics of the first stage have not been altered by the additive, but the time at which it begins was advanced by adding ozone, which stimulated early heat release.

The major intermediate being produced is still $\mathrm{H}_{2} \mathrm{O}_{2}$, and it still decomposes at $950-1000 \mathrm{~K}$, producing the real ignition. The ozone additive advances the time of ignition from about $14 \mathrm{msec}$ after TDC to about $9 \mathrm{msec}$ after TDC. The second stage ignition is the same in both cases, but the addition of ozone makes that mixture reach the ignition temperature at an earlier time. Finally, note the peak in $O$ atom concentration that occurs at each of the three stages of ignition, at times of $-6,+1$ and $+9 \mathrm{msec}$ after TDC.

\section{Engine Knock}

In spark ignition engines, thermodynamic combustion efficiency increases with engine compression ratio. However, increased compression ratio eventually results in engine knock, limiting engine efficiency in practical engines. Numerical studies have used reduced [70-74] and detailed [66,74-78] kinetic models to understand chemical factors responsible for knock. 
In a spark ignition engine, a flame propagates through a combustion chamber, starting at the point of spark ignition. Some reactant gases in the combustion chamber will naturally be the last to be consumed by the flame, termed the "end gases". End gas conditions are determined by piston motion and combustion in the engine chamber. As piston motion and flame propagation proceed, end gases see increasing levels of pressure and temperature and react accordingly. If end gases reach the point of ignition before being consumed by the flame, knocking behavior will be observed. Mixtures that react more rapidly are more susceptible to knock, while mixtures that ignite more slowly resist knock. Increasing the engine compression ratio increases the rate of autoignition while having little effect on flame propagation, so this increases the potential for knocking behavior. Thus engine knock is essentially an ignition problem.

Computational modeling of autoignition at engine conditions shows the same features as described for the rapid compression machine. This can be illustrated by examining the way that fuel composition, molecular size and structure influence autoignition behavior and tendency to knock by simulating the critical compression ratio. Experiments are carried out in a CFR engine at a low engine speed of $600 \mathrm{rpm}$ and intake manifold temperature of $403 \mathrm{~K}$. These are essentially the same conditions as those in standardized tests for research octane number (RON). For stoichiometric fuel/air mixtures, the engine compression ratio is steadily increased until autoignition is observed. A series of such experiments were carried out by Leppard [79] for a range of alkane and primary reference fuel mixtures, and a kinetic model was used to simulate those experiments [66,72]. Computed and experimental critical compression ratio results are plotted in Figure 5, together with measured research octane numbers 
of each fuel. A rather smooth curve results, although it is clearly not a straight line, indicating that octane rating is a rather nonlinear scale.

A numerical experiment can be carried out to use this information to construct a fuel mixture with an arbitrary. octane rating. For example, to create a fuel with a research octane number (RON) of 90.8 , a motor octane number $(\mathrm{MON})$ of 83.9 , and an overall octane rating $(\mathrm{RON}+\mathrm{MON}) / 2$ of 89 , to compare with ordinary gasoline, a mixture of two isomers of hexane and two isomers of pentane was defined in terms of their individual RON and MON values. These four fuel components are indicated by the arrows in Fig. 5. When tested numerically, this mixture had a critical compression ratio corresponding to a RON of 90.4 , very close to the blending value, as shown in Fig 5.

A critical feature of these'computed histories is that they reach peak compression temperatures that are all very nearly the same. Considerable differences in octane number result in only a few degrees of temperature at top dead center (TDC), resulting in considerable difference in time of ignition and demonstrating that the octane number scale is highly nonlinear.

Just as observed in the RCM results, these computed results indicate that ignition in each of these cases occurs when $\mathrm{H}_{2} \mathrm{O}_{2}$ decomposes. Differences in octane number are reflected in small differences in cool flame heat release, with greater amounts of low temperature heat release and higher quantities of $\mathrm{H}_{2} \mathrm{O}_{2}$ correlating with earlier ignition and lower octane values. Similar conclusions were obtained by Blin-Simiand et al. concerning the central role of $\mathrm{H}_{2} \mathrm{O}_{2}$ decomposition and its role in autoignition [103]. 
The effects of various antiknock compounds can be understood in this same framework. Additives including tetraethyl lead, now no longer used, provide kinetic sinks for $\mathrm{HO}_{2}[58,80,81]$, greatly reduce the production of $\mathrm{H}_{2} \mathrm{O}_{2}$ and interfere with the intermediate temperature ignition process. Other additives including methyl tert-butyl ether (MTBE) act by interfering with low temperature oxidation $[18,58]$, reducing the amount of low temperature heat release, and retarding the time at which the end gas reaches the $\mathrm{H}_{2} \mathrm{O}_{2}$ decomposition temperature.

\section{Diesel ignition}

Diesel engines have existed for many years, but until recently many of the basic physical and chemical principles of diesel combustion had not been well understood. Recently, in a series of insightful laser diagnostic studies, Dec provided a coherent, self-consistent picture of diesel combustion [82]. His results, summarized in Figure 6, show that the fuel jet vaporizes rapidly and mixes with hot, compressed air. The air steadily reduces the fuel/air equivalence ratio at the same time that it is increasing the mixture temperature, and the mixture begins to react. In Dec's observations, this mixture eventually ignites while the equivalence ratio is still quite high $(\phi \approx 4)$. Soot production was observed to proceed immediately from the products of this rich, premixed ignition, and soot is consumed in a diffusion flame at the periphery of the downstream cloud.

This large scale ignition problem has been analyzed using detailed chemical kinetics [83]. The premixed region begins to react when the local 
equivalence ratio reaches $\phi \approx 10$, although the rate of reaction is initially quite slow. As air mixes and the mixture temperature increases, the rate of reaction increases. Rapid reaction begins when the mixture temperature reaches about 700K. As noted above for other classes of applications, this low temperature reaction produces $\mathrm{H}_{2} \mathrm{O}_{2}$ and produces a modest amount of heat release and temperature increase. Eventually the mixture reaches the temperature where $\mathrm{H}_{2} \mathrm{O}_{2}$ decomposes and ignition is observed. Thus the kinetic mechanism of diesel ignition is identical with that of the RCM and that of engine knock in spark-ignition engines. The major differences occur because diesel ignition takes place under very fuel-rich conditions.

Diesel ignition improvers [84] are species like ethyl-hexyl nitrate that decompose at temperatures much lower than the ignition temperature provided by $\mathrm{H}_{2} \mathrm{O}_{2}$ decomposition. Radicals produced by decomposition of the additive consume some fuel and release some heat, raising the temperature of the premixed gases and getting them closer to the $\mathrm{H}_{2} \mathrm{O}_{2}$ decomposition temperature. Other additives that decompose at lower temperatures and provide radicals would also be effective diesel ignition improvers or cetane improvers. The example of ozone discussed earlier for the RCM would enhance diesel ignition in this same manner.

An especially interesting additional feature of this premixed ignition is the observation by Dec that the products of the rich premixed ignition immediately begin the process of soot precursor and soot production. In computed models of this rich premixed ignition [83], the products of the ignition are the same species 
that have been shown [85-88] to preferentially produce small aromatic ring species such as benzene, toluene and naphthalene. Small aromatic species then react to produce larger polycyclic aromatic species and eventually soot. It has been shown experimentally [89] that addition of oxygenated species to the fuel can reduce soot emissions in diesel combustion, and this trend has been reproduced by kinetic modeling [83] by correlating the total product concentrations of aromatic formation precursors with the amounts of these simple species that survive the premixed rich ignition stage. Thus soot production is directly related to ignition kinetics in the diesel engine.

Figure 7 shows concentrations of soot produced in diesel engines with the relative amounts of oxygenates in the fuel from the experimental work of Miyamoto et al. [89]. Also shown is the total concentration of ethene, acetylene, and propargyl radical, summed together, to roughly produce a curve similar to that derived experimentally by Miyamoto et al. These modeling calculations [83] were carried out for a variety of oxygenated species (i.e., methanol, ethanol, dimethyl ether, dimethoxy methane, methyl butanoate) added to n-heptane; nheptane is a realistic surrogate diesel fuel with a cetane number of 56 . This work suggests strongly that rich premixed ignition does indeed produce the seeds of soot formation, and that lowering the post-ignition concentrations of these elementary species effectively reduces soot production. The sequence of fuel/air mixing, rich premixed ignition and production of soot precursors, followed eventually by soot burnout, provides a framework for diesel combustion in which each of the detailed steps leads very naturally and continuously to the next step. 


\section{Homogeneous Charge, Compression Ignition (HCCI)}

Combustion in reciprocating engines under homogeneous charge, compression ignition (HCCI) conditions is an intriguing technology that may offer the opportunity to eliminate $\mathrm{NO}_{\mathrm{x}}$ emissions from engine combustion. Particulate emissions are also observed to be very low. Disadvantages are high unburned hydrocarbon and $\mathrm{CO}$ emissions, along with high peak pressures and high rates of heat release.

In an $\mathrm{HCCl}$ engine, a premixed, very lean mixture of fuel and air is drawn into the engine chamber and compressed by a piston. Near TDC the majority of the charge in the engine ignites homogeneously. The time of ignition can be varied by changing compression ratio, fuel/air equivalence ratio, the time of intake valve opening, and intake manifold temperature.

$\mathrm{HCCl}$ was identified as a distinct combustion phenomenon about 20 years ago. Initial studies [90-92] recognized the basic characteristics of HCCI; ignition occurs at many points simultaneously, with no flame propagation. It is controlled primarily by chemical ignition kinetics, with little influence from effects such as turbulence or mixing that play such a large role in other engine combustion problems. Simplified kinetics models have been used to analyze HCCI combustion, coupled usually to multidimensional CFD models [93-97], with limited success.

Recently, detailed kinetic modeling has been used to examine HCCI combustion [97-99]. For a number of practical fuels, including natural gas, propane and others, model calculations have reproduced the onset of ignition in good agreement with experimental results carried out at the Lund Institute of 
Technology $[100,101]$, using a spatially homogeneous model. The product temperature is kept low by operating at very lean conditions, so temperatures are too low to produce significant $\mathrm{NO}_{\mathrm{x}}$ emissions. However, a one-zone, homogeneous treatment produces much too rapid a combustion duration, as shown in Figure 8, and cannot predict $\mathrm{CO}$ and hydrocarbon emissions.

$\mathrm{HCCI}$ engine wall temperatures are low, so there is an extensive engine chamber thermal boundary layer, and not all the boundary layer fuel burns together with the initial bulk ignition. In addition, there is unburned fuel in piston ring and other crevice volumes that does not burn immediately. Since the peak bulk temperatures are low and decrease further after TDC, most fuel in the boundary layer and crevices cannot diffuse out into the bulk gas and burn; this material is ultimately exhausted without further reaction. However, some fraction of these gases can be partially burned, resulting in products of incomplete combustion and especially $\mathrm{CO}$.

A full kinetic, spatially varying model [98] can account for the temperature distribution in the boundary layer and crevices, in addition to the main bulk charge, to predict unburned hydrocarbon and $\mathrm{CO}$ emissions from this engine. As a result of this varying temperature distribution in the fuel/air mixture, the overall heat release is spread out in time relative to the one-zone homogeneous treatment, in much better agreement with experimental results, as shown in Fig. 8 for cases in which the bulk region and boundary layer were defined by 10 spatial zones. This more refined model describes many experimental features of HCCI very well except for the predicted $\mathrm{CO}$ emissions, as shown in Figure 9. 
The kinetic details of these model computations indicate that $\mathrm{HCCI}$ ignition is controlled by $\mathrm{H}_{2} \mathrm{O}_{2}$ decomposition. Computed variations in selected species concentrations are summarized in Figure 10, in which it is clear that $\mathrm{H}_{2} \mathrm{O}_{2}$ decomposition occurs at the time of autoignition, observed experimentally [99] to occur at about $1^{\circ}$ after TDC. The fuel/air mixture follows a temperature and pressure history very similar to those encountered by end gases in sparkignition engines and in a rapid compression machine. Modest heat release occurs at lower temperatures, depending on the cool flame reactivity of the specific fuel or fuel mixture, resulting in variable amounts of early temperature increase. Variation in any engine parameter that gets the reactive fuel/air mixture to the $\mathrm{H}_{2} \mathrm{O}_{2}$ decomposition temperature of about $1000 \mathrm{~K}$ earlier will advance ignition, and anything that delays reaching that temperature will retard ignition. Increasing the intake manifold temperature and use of pro-ignition additives such as ozone (see Fig. 4) or ethyl-hexyl nitrate advance igntion, while exhaust gas recirculation (EGR) and addition of knock suppressants retard ignition.

In many ways, $\mathrm{HCCI}$ combustion is very simple. Low and intermediate temperature reaction sequences process the fuel/air mixture during its compression; the amount of low temperature, cool flame heat release varies, depending on the composition of the fuel. Ignition occurs at the temperature where the core fuel/air charge reaches the $\mathrm{H}_{2} \mathrm{O}_{2}$ decomposition temperature, so models developed for engine knock and rapid compression machines are directly 
applicable to $\mathrm{HCCI}$ systems. Low $\mathrm{NO}_{x}$ production is a result of the very low overall fuel/air equivalence ratio; the low equivalence ratio is possible because flame propagation is not required in the HCCI engine [102]. Combustion is spread out in time because the extended boundary layer reacts later than the core gases. High hydrocarbon and $\mathrm{CO}$ emissions are an inevitable result of the low bulk gas temperatures and wall boundary layers, and it is very likely that postcombustion, exhaust gas treatments will be necessary to make HCCI combustion viable. If low temperature hydrocarbon catalysts were to become available, HCCI would represent an important competitor to conventional spark-ignition and diesel engines.

\section{Summary}

The role of chain branching in determining the onset of ignition has identified two distinct chain branching mechanisms affecting hydrocarbon ignition in practical systems. The high temperatures (above $\sim 1200 \mathrm{~K}$ ), mechanism is important in shock tube ignition and practical systems including detonations and pulse combustors. These are primarily thermal ignitions, where heat release increases the temperature, further increasing the rate of ignition until reactant depletion ends the ignition.

The second chain branching regime depends on $\mathrm{H}_{2} \mathrm{O}_{2}$ decomposition at about $900-1000 \mathrm{~K}$. Experiments in rapid compression machines and flow reactors and corresponding model calculations confirm the importance of $\mathrm{H}_{2} \mathrm{O}_{2}$ decomposition kinetics and provide insight into the mechanisms of ignition. 
When these models are then applied to practical systems, especially in engine environments, it is clear that the same kinetic features control ignition in all of these systems. Modifications of the combustion environment that enable a system to reach the decomposition temperature at earlier times advance ignition, while modifications that delay reaching that temperature retard ignition.

This analysis shows that autoignition in engines is dominated by only one elementary reaction, $\mathrm{H}_{2} \mathrm{O}_{2}$ decomposition. Low temperature reactions or cool flames, including the highly chain branched alkylperoxy radical isomerization kinetic system, simply advance the time at which $\mathrm{H}_{2} \mathrm{O}_{2}$ decomposition is observed. This simplifies the analysis of combustion ignition phenomena and focuses kinetic attention on a very limited family of reactions that control autoignition phenomena in a very wide range of practical systems.

\section{ACKNOWLEDGMENTS}

The many contributions of colleagues are gratefully noted, including Bill Pitz, Henry Curran, Fred Dryer, Bill Leppard, Nick Marinov, Nick Cernansky, John Griffiths, Jürgen Warnatz, Jim Miller, Pat Flynn, Bengt Johansson, Magnus

Christensen and many others who have provided experimental data, theoretical insight, hard work, and encouragement. Kinetic modeling is a collaboration in many ways, and the insights provided by the present work are the collective product of all of these individuals. This work has been carried out under the auspices of the U.S. Department of Energy by University of California Lawrence Livermore National Laboratory under Contract W-7405-Eng-48. 
References

1. Griffiths, J. F., and Barnard, J. A., "Flame and Combustion", Chapman and Hall, London (1995).

2. Laidler, K. J., "Chemical Kinetics", 3rd edition, Harper and Row, New York (1987).

3. Glassman, I., "Combustion", Academic Press, New York (1977).

4. Bowes, P. C., "Self-Heating: Evaluating and Controlling the Hazard", HMSO Books, London (1984).

5. Semenov, N. N., "Chemical Kinetics and Chain Reactions", Oxford University Press, Oxford, UK (1935).

6. Hinshelwood, C. N., "The Kinetics of Chemical Change", Clarendon Press, Oxford (1940).

7. Frenklach, M., Wang, H., and Rabinowitz, M. J., Prog. Energy Combust. Sci. 18, 47-73 (1992).

8. Westbrook, C. K. Combust. Sci. Technol. 20, 5-17 (1979).

9. Warnatz, J., Proc. Combust. Inst. 18: 369-384 (1981).

10. Westbrook, C. K., and Pitz, W. J., Proc. 15th Int. Symp. Shock Waves and Shock Tubes. Shock Waves and Shock Tubes, D. Bershader and R. Hanson, eds., Stanford Univ. Press, Stanford, CA, 1986.

11. Yetter, R.A., Dryer, F.L., and Rabitz, H., Comb. Sci. Tech. 79, 97-128 (1991).

12. Curran, H. J., Simmie, J. M., Dagaut, P., Voisin, D., and Cathonnet, M., Proc. Combust. Inst. 26: 613-620 (1996).

13. Burcat, A., Scheller, K. and Lifshitz, A., Combust. Flame 16, 29-33 (1971).

14. Dixon-Lewis, G., Combust. Flame $\underline{36} 1$ (1979).

15. Westbrook, C. K., Combust. Sci. Technol. 23 191-202 (1980).

16. Westbrook, C. K., Proc. Combust. Inst. 19: 127-141 (1983).

17. Moen, I. O., Ward, S. A., Thibault, P. A., Lee, J. H., Knystautas, R., Dean, T., and Westbrook, C. K., Proc. Combust. Inst. 20: 1717-1725 (1985).

18. Gray, J. A., and Westbrook, C. K., Int. J. Chem. Kinet. 26, 757-770 (1994). 
19. Westbrook, C. K., Combust. Sci. Technol. $\underline{34}$ 201-225 (1983).

20. Ciezki, H. K., and Adomeit, G., Combust. Flame 93 421-433 (1993).

21. Davidson, D.F., Petersen, E.L., Rohrig, M., Hanson, R.K., and Bowman, C.T., Proc. Combust. Inst. 26: 481-488 (1996).

22. Strehlow, R. A., Combust. Flame 12, 81-101 (1968).

23. Nettleton, M. A., "Gaseous Detonations, their nature, effects and control", Chapman and Hall, New York (1987).

24. Taki, S., and Fujiwara, T., Proc. Combust. Inst. 18: 1671-1681 (1981).

25. Kailasanath, K., Oran, E.S., Boris, J.P.; and Young, T., Combust. Flame $\underline{61}$ 199-209 (1985).

26. Zeldovich, Ya. B., J. Exp. Theor. Phys. USSR 10, 524 (1940).

27. von Neumann, J., Progress Report on the theory of detonation waves. OSRD Rept. No. 549 (1942).

28. Döring, W., Ann. Physik $\underline{43} 421$ (1943).

29. Atkinson, R., Bull, D.C., and Shuff, P.J., Combust. Flame 39, 287 (1980).

30. Westbrook, C. K., Combust. Flame 46, 191-210 (1982).

31. Westbrook, C. K., Combustion Science and Technology $\underline{29}$ 67-81 (1982).

32. Westbrook, C. K., Proc. Combust. Inst. 19: 127-141 (1983).

33. Westbrook, C.K., and Urtiew, P.A., Proc. Combust. Inst. 19: 615-623 (1983).

34. Westbrook, C. K., and Urtiew, P. A., Fizika Goreniya y Fizryva 19, No. 6, pp. 65-76 (1983).

35. Shepherd, J., AIAA Progress in Astronautics and Aeronautics: Dynamics of Reactive Systems, vol. 106 (edited by J.R. Bowen, J.-C. Leyer, and R. I. Soloukhin), pp. 263-293, AIAA, New York.

36. Matsui, H., and Lee, J. H. S., Proc. Combust. Inst. 17: 1269-1280 (1979).

37. Tieszen, S. R., Stamps, D. W., Westbrook, C. K., and Pitz, W. J., Combustion and Flame $\underline{84}$, 376-390 (1990).

38. Melius, C. F., in Chemistry and Physics of Energetic Materials, Kluwer, Netherlands, pp. 51-78 (1990). 
39. Yetter, R. A., Dryer, F. L., Allen, M. T., and Gatto, J. L., J. Propulsion Power 11, 683-697 (1995).

40. Prasad, K., Yetter, R. A., Smooke, M. D., Parr, T. P., and Hanson-Parr, D. M., AIAA 34th Aerospace Sciences meeting, Reno, January 1996. AIAA paper 96-0880 (1996).

41. Tanoff, M. A., Ilincic, N., Smooke, M. D., Yetter, R. A., Parr, T. P., and Hanson-Parr, D. M., Proc. Combust. Inst. 27: 2397-2404 (1998).

42. Keller, J. O., and Westbrook, C. K., Proc. Combust. Inst. 21: 547-555 (1986).

43. Keller, J. O., Bramlette, T. T., Dec, J. E., and Westbrook, C. K., Combustion and Flame $\underline{75}$, 33-44 (1989).

44. Barr, P. K., Keller, J. O., Bramlette, T. T., Westbrook, C. K., and Dec, J. E., Combustion and Flame 82, 252-269 (1990).

45. Keller, J. O., Bramlette, Westbrook, C. K., and Dec, J. E., Combust. Flame $\underline{79}$ 151-161 (1990).

46. ' Liss, W. E., Thrasher, W. H., Steinmetz, G. F., Chowdiah, P., and Attari, A., "Variability of Natural Gas Composition in Select Major Metropolitan Areas of the United States," GRI Report 92-0123 (1992).

47. Held, T. J., and Dryer, F. L., Proc. Combust. Inst. 25: 901-908 (1994).

48. Koert, D. N., Pitz, W. J., Bozzelli, J. W., and Cernansky, N. P., Proc. Combust. Inst. 26: 633-640 (1996).

49. Dagaut, P., Reuillon, M., and Cathonnet, M., Combust. Flame 101, 132-140 (1995).

50. Griffiths, J. F., Halford-Maw, P. A., and Rose, D. J., Combust. Flame 95, 291306 (1993).

51. Minetti, R., Carlier, M., Ribaucour, M., Therssen, E., and Sochet, L. R., Combust. Flame 102, 298-309 (1995).

52. Park, P., and Keck, J. C., Society of Automotive Engineers SAE-900027 (1990).

53. Ribaucour, M., Minetti, R., Sochet, L. R., Curran, H. J., Pitz, W. J., and Westbrook, C. K., submitted for publication (2000).

54. Cox, A., Griffiths, J., Mohamed, C., Curran, H.J., Pitz, W., and Westbrook, C.K., Proc. Combust. Inst. 26: 2685-2692 (1996). 
55. Westbrook, C.K., Curran, H.J., Pitz, W.J., Griffiths, J.F., Mohamed, C., and Wo, S.K., Proc. Combust. Inst. 27: 371-378 (1998).

56. Pollard, R. T., Comprehensive Chemical Kinetics, vol. 17, C. H. Bamford and C. F. H. Tipper, Eds., Elsevier, New York, pp. 249-367 (1977).

57. Westbrook, C. K., Creighton, J., Lund, C. M., and Dryer, F. L., J. Phys. Chem. 81, 2542-2554 (1977).

58. Westbrook, C. K., Pitz,W. J., and Leppard, W. R., Society of Automotive Engineers publication SAE-912314. SAE Trans. 100, pp. 605-622 (1991).

59. Baldwin, R. R., Pickering, I. A., and Walker, R. W., J.C.S. Faraday I 76, 23742382 (1980).

60. McAdam, K. G., and Walker, R. W., J. C. S. Faraday Trans. $2 \underline{83}$ 1509-1517 (1987).

61. Wagner, A. F., Slagle, I. R., Sarzynski, D., and Gutman, D., J. Phys. Chem. 94, 1853-1868 (1990).

62. Bozzelli, J. W., and Dean, A. M., J. Phys. Chem. 94 3313-3317 (1990). Also Venkatesh, P. K., Dean, A. M., Cohen, M. H., and Carr, R. W., J. Chem. Phys. 111, 8313-8329 (1999).

63. Miller, J.A., Klippenstein, S.J., and Robertson, S.H., Proc. Combust. Inst. 288: in press (2000).

64. Bozzelli, J. W., and Pitz, W. J., Proc. Combust. Inst. 25: 783-791 (1994).

65. Koert, D. N., Pitz, W. J., Bozzelli, J. W., and Cernansky, N. P., Proc. Combust. Inst. 26: 633-640 (1996).

66. Curran, H. J., Gaffuri, P., Pitz, W. J., Westbrook, C. K., and Leppard, W. R., Proc. Combust. Inst. 26: 2669-2677 (1996).

67. Curran, H. J., Gaffuri, P., Pitz, W. J., and Westbrook, C. K., Combust. Flame 114, 149-177 (1998).

68. Benson, S. W., Proc. Combust. Inst. 21: 703-711 (1986).

69. Benson, S. W., J. Am. Chem. Soc. 87,972 (1965).

70. Halstead, M. P., Kirsch, L. J., Prothero, A., and Quinn, C. P., Proc. Roy. Soc. A346, 515 (1975).

71. Morley, C., Proc. Combust. Inst. 22: 911-918 (1988).

72. Cox, R. A., and Cole, J. A., Combust. Flame 60 109 (1985). 
73. Hu, H., and Keck, J., Society of Automotive Engineers SAE-872110 (1987).

74. Cowart, J. S., Keck, J. C., Heywood, J. B., Westbrook, C. K., and Pitz, W. J., Proc. Combust. Inst. 23: 1055-1062 (1990).

75. Smith, J. R., Green, R. M., Westbrook, C. K., and Pitz, W. J., Proc. Combust. Inst. 20: 91-100 (1985).

76. Cernansky, N. P., Green, R. M., Pitz, W. J., and Westbrook, C. K., Combust. Sci. Technol. 50 3-25 (1986).

77. Westbrook, C. K., Warnatz, J., and Pitz, W. J., Proc. Combust. Inst. 22: 893901 (1988).

78. Chevalier, C., Pitz, W. J., Warnatz, J.; Westbrook, C. K., and Melenk, H., Proc. Combust. Inst. 24: 93-101 (1992).

79. Leppard, W. R., unpublished engine studies.

80. Benson, S. W., J. Phys. Chem. 92, 1531-1533 (1988).

81. Pitz, W. J., and Westbrook, C. K., Combust. Flame 63, 113-133 (1986).

82. Dec, J. E., Society of Automotive Engineers, SAE 970873 (1997).

83. Flynn, P. F., Durrett, R. P., Hunter, G. L., zur Loye, A. O., Akinyemi, O. C., Dec, J. E., and Westbrook, C. K., Society of Automotive Engineers, SAE1999-01-0509 (1999).

84. Stein, Y., Yetter, R.A., Dryer, F.L., and Aradi, A., Society of Automotive Engineers, SAE-1999-01-1504 (1999).

85. Frenklach, M., and Wang, H., Proc. Combust. Inst. 23: 1559-1566 (1990).

86. Marinov, N.M., Pitz, W.J., Westbrook, C.K., Vincitore, A.M., Castaldi, M.J., Senkan, S.M., and Melius, C.F., Combust. Flame 114, 192-213 (1998).

87. Harris, S.J., Weiner, A.M., Blint, R.J., and Goldsmith, J.E.M., Proc. Combust. Inst. 21: 1033-1045 (1986).

88. Miller, J. A., and Melius, C. F., Combust. Flame 91 21-39 (1992).

89. Miyamoto, N., Ogawa, H., Nurun, N.M., Obata, K., Arima, T., Society of Automotive Engineers publication SAE-980506, 1998.

90. Onishi, S., Jo, S. H., Shoda, K., Jo, P. D., and Kato, S., Society of Automotive Engineers SAE-790501 (1979). 
91. Noguchi, M., Tanaka, Y., Tanaka, T., and Takeuchi, Y., Society of Automotive Engineers SAE-790840 (1979).

92. Najt, P. M., and Foster, D. E., Society of Automotive Engineers SAE830264 (1983).

93. Akagawa, H., Miyamoto, T., Harada, A., Sasaki, S., Shimazaki, N., Hashizuma, T., and Tsujimura, K., Society of Automotive Engineers SAE1999-01-0183 (1999).

94. Yokota, H., Kudo, Y., Nakajima, H., Kakegawa, T., and Suzuki, T., Society of Automotive Engineers SAE-970891 (1997).

95. Ishii, H., Koike, N., Suzuki, H., and Odaka, M., Society of Automotive Engineers SAE-970315 (1997).

96. Hashizume, T., Miyamoto, T., Akagawa, H., and Tsujimura, K., Society of Automotive Engineers SAE-980505 (1998).

97. Aceves, S. M., Smith, J. R., Westbrook, C. K., and Pitz, W. J., ASME J. Engin. Gas Turb. Power 121, 569-574 (1999).

98. Aceves, S. M., Flowers, D. L., Westbrook, C. K., Smith, J. R., Pitz, W. J., Dibble, R., Christensen, M., and Johansson, B., Society of Automotive Engineers SAE-2000-01-0327 (2000).

99. Kelly-Zion, P. L., and Dec, J. E., Proc. Combust. Inst. 28:, in press (2000).

100. Christensen, M., Johansson, B., Amneus, P., and Mauss, F., Society of Automotive Engineers SAE-980787 (1998).

101. Christensen, M., Johansson, B., and Einewall, P., Society of Automotive Engineers SAE-972874 (1997).

102. Flynn, P. F., Hunter, G. L., Farrell, L. A., Durrett, R. P., Akinyemi, O. C., zur Loye, A. O., Westbrook, C. K., and Pitz, W. J. Proc. Combust. Inst. 28: in press (2000).

103. Blin-Simiand, N., Rigny, R., Viossat, V., Circan, S., and Sahetchian, K., Combust. Sci. Technol. $\underline{88}$ 329-348 (1993). 


\section{FIGURE CAPTIONS}

1. Ignition delay times for $C_{1}-C_{5}$ alkanes. Experimental data are from Burcat et al. [13], computed lines are Westbrook and Pitz. [10]. The dark dashed line is a fit to the experimental results for ethane ignition from [13], and no computed results for ethane ignition were carried out. Experimental points: open triangles - methane; filled circles - propane; filled squares - $n$-pentane; open squares - $n$-butane.

2. Computed temperature and concentrations of neo-pentane, $\mathrm{H}_{2} \mathrm{O}_{2}$ and $\mathrm{OH}$ from Ribaucour et al. [53].

3. Computed temperatures in ignition of the three isomers of pentane, from Ribaucour et al. [53].

4. Computed temperature and selected species concentrations from rapid compression machine ignition of neo-pentane. Same initial conditions as Figure 2, but with $10 \mathrm{ppm}$ ozone included.

5. Correlation of computed critical compression ratio with research octane numbers. Solid circles are primary reference fuel mixtures, other symbols are isomers of hexane and pentane, stars are experimentally measured values [66].

6. Schematic model of diesel spray combustion, based on work of Dec [82]. The ignition region is identified, and the temperatures of the different regions in the combusting spray are noted.

7. Experimentally observed variation in Bosch smoke number with fuel oxygenate content, from Miyamoto et al. [89], and variation in computed soot precursor concentrations with fuel oxygenate content, from Flynn et al. [83].

8. Comparison between experimental pressure traces [100] and calculated values, using both a single-zone and a 10 zone modeling treatment [97], for three natural gas experiments at different boost pressures.

9. Ratios of experimental [100] to numerical results [97] for the main combustion parameters of $\mathrm{HCCI}$, for natural gas at different boost pressures, using the 10 zone spatial model.

10. Computed concentrations of basic species in parts per million in the bulk gases in HCCI ignition, with natural gas fuel [97]: 


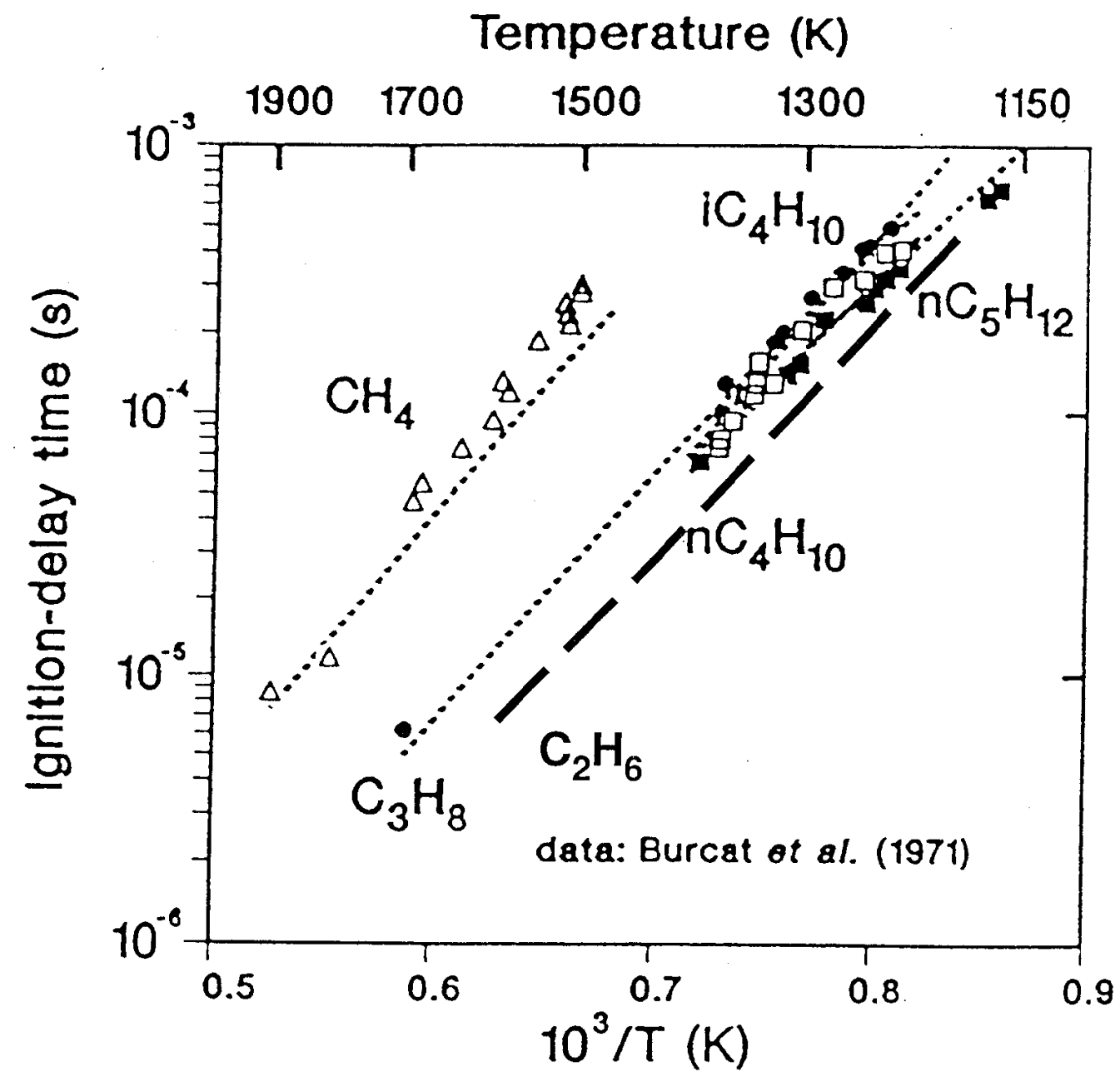



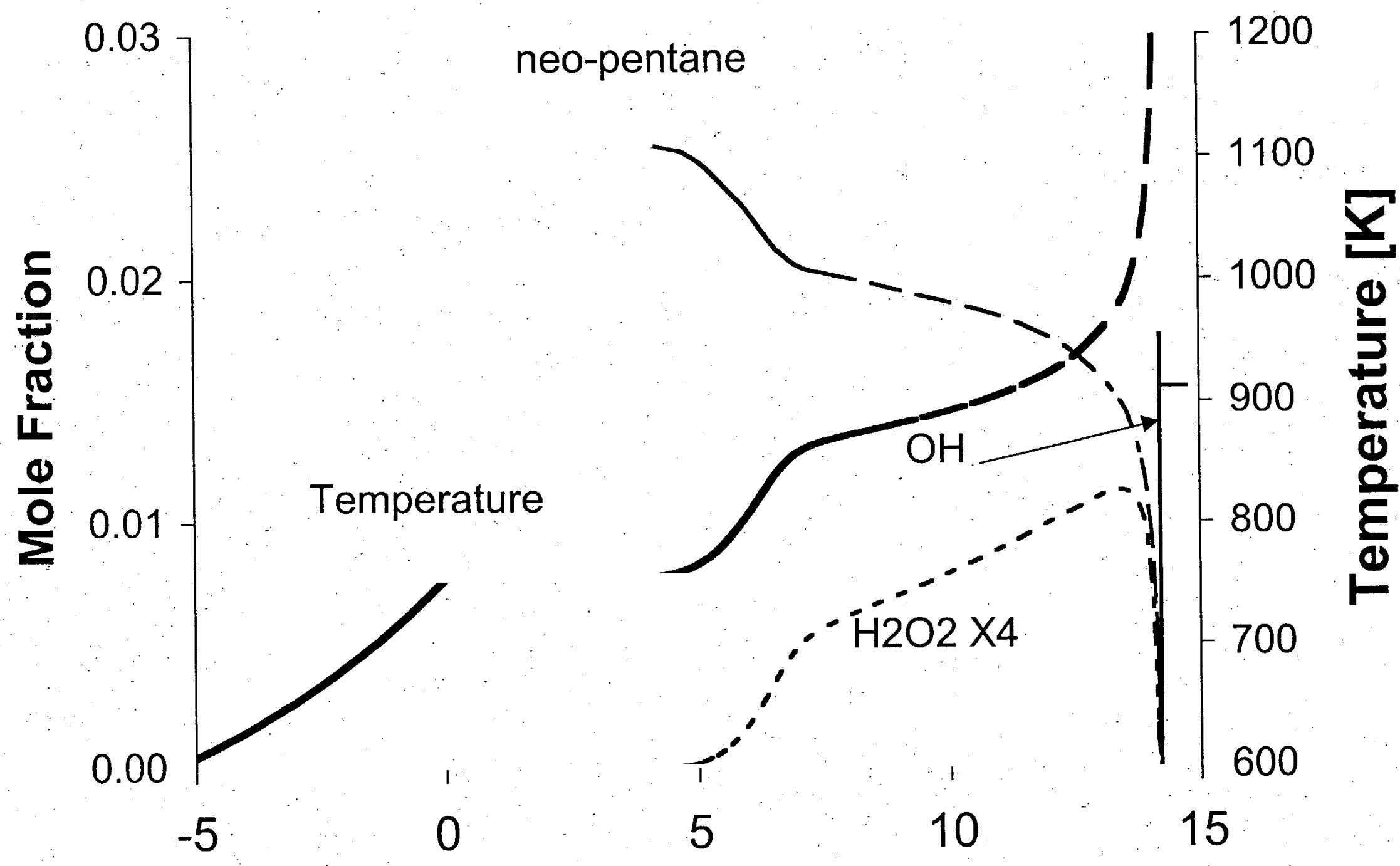

Time after TDC [ms] 


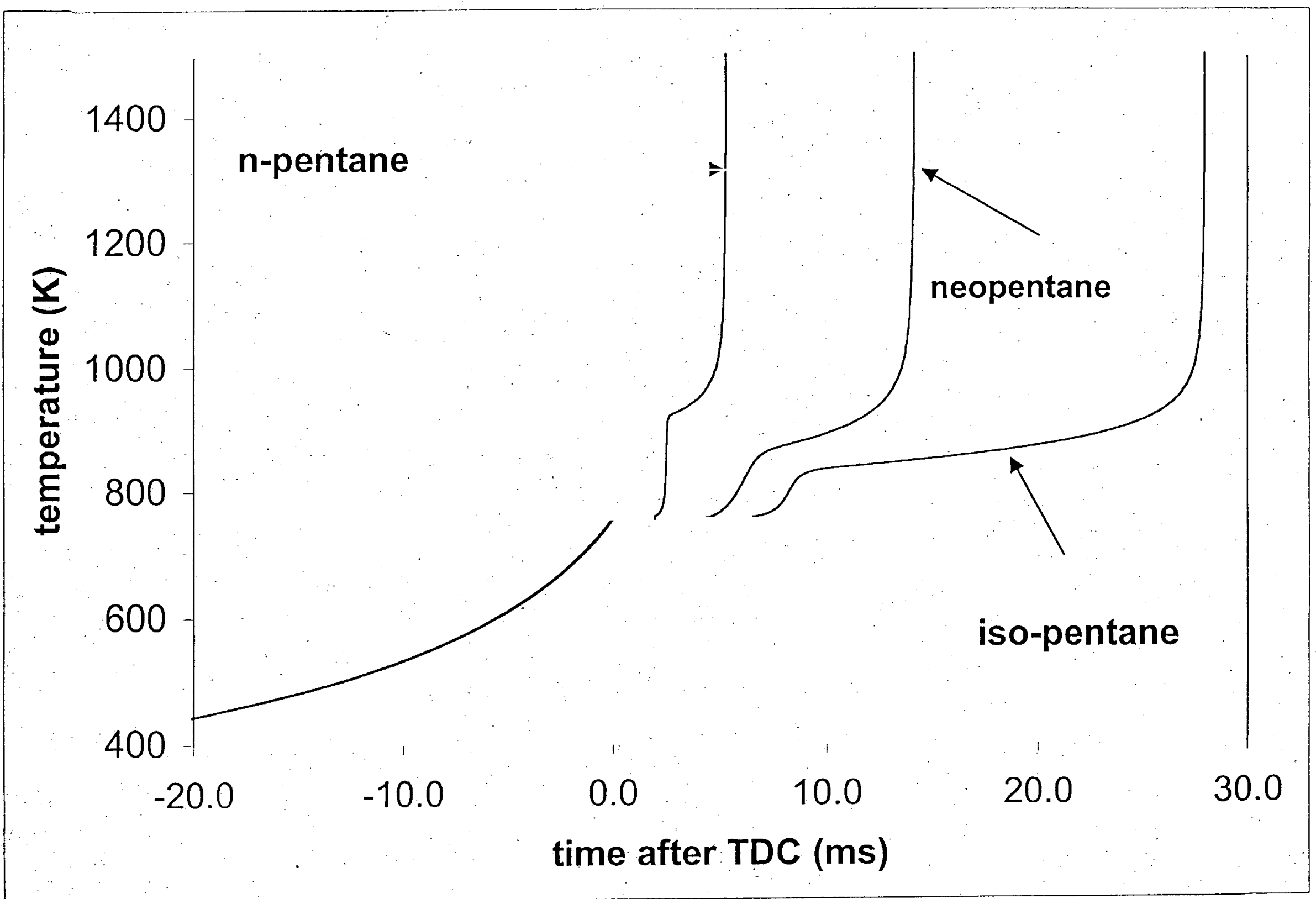




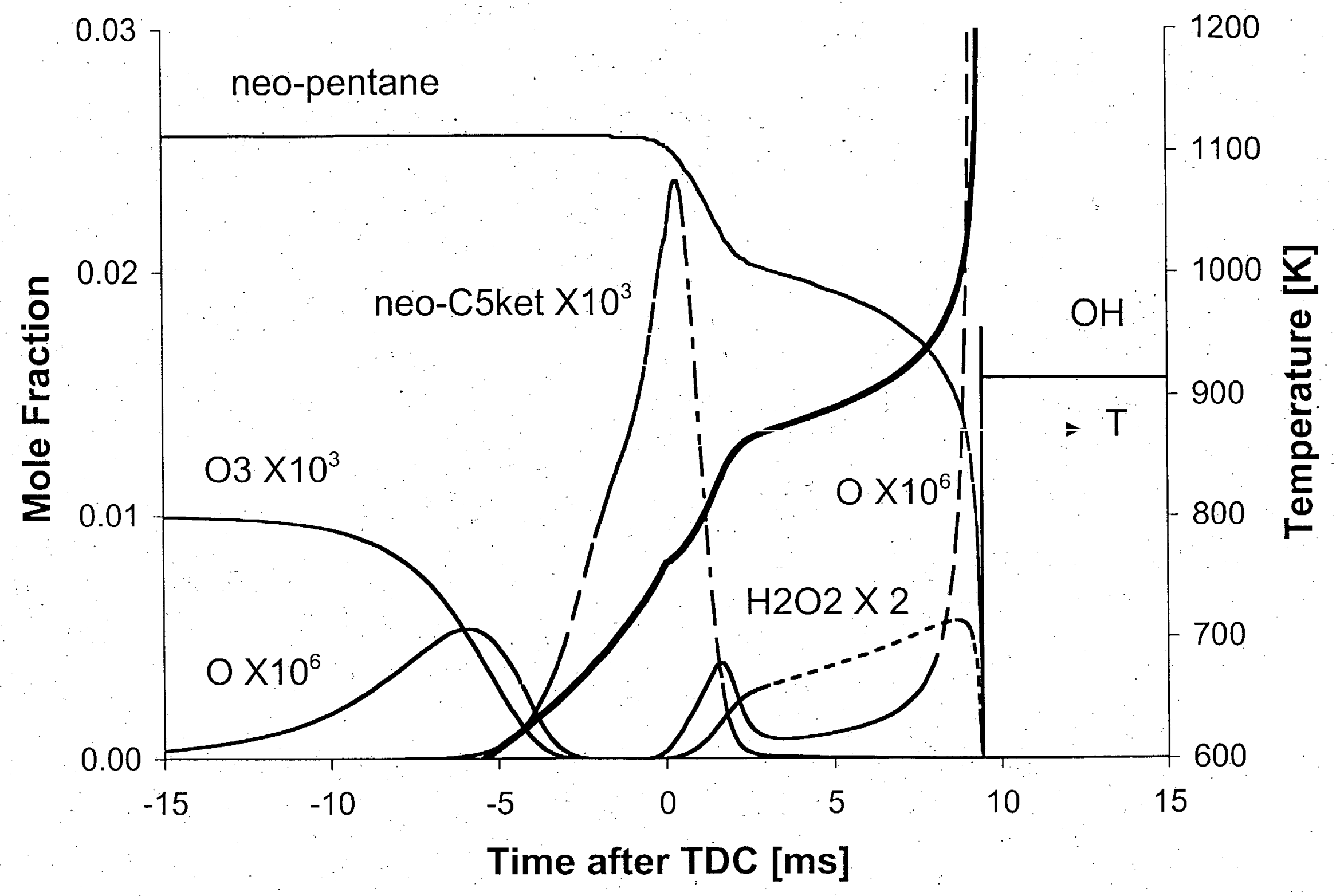




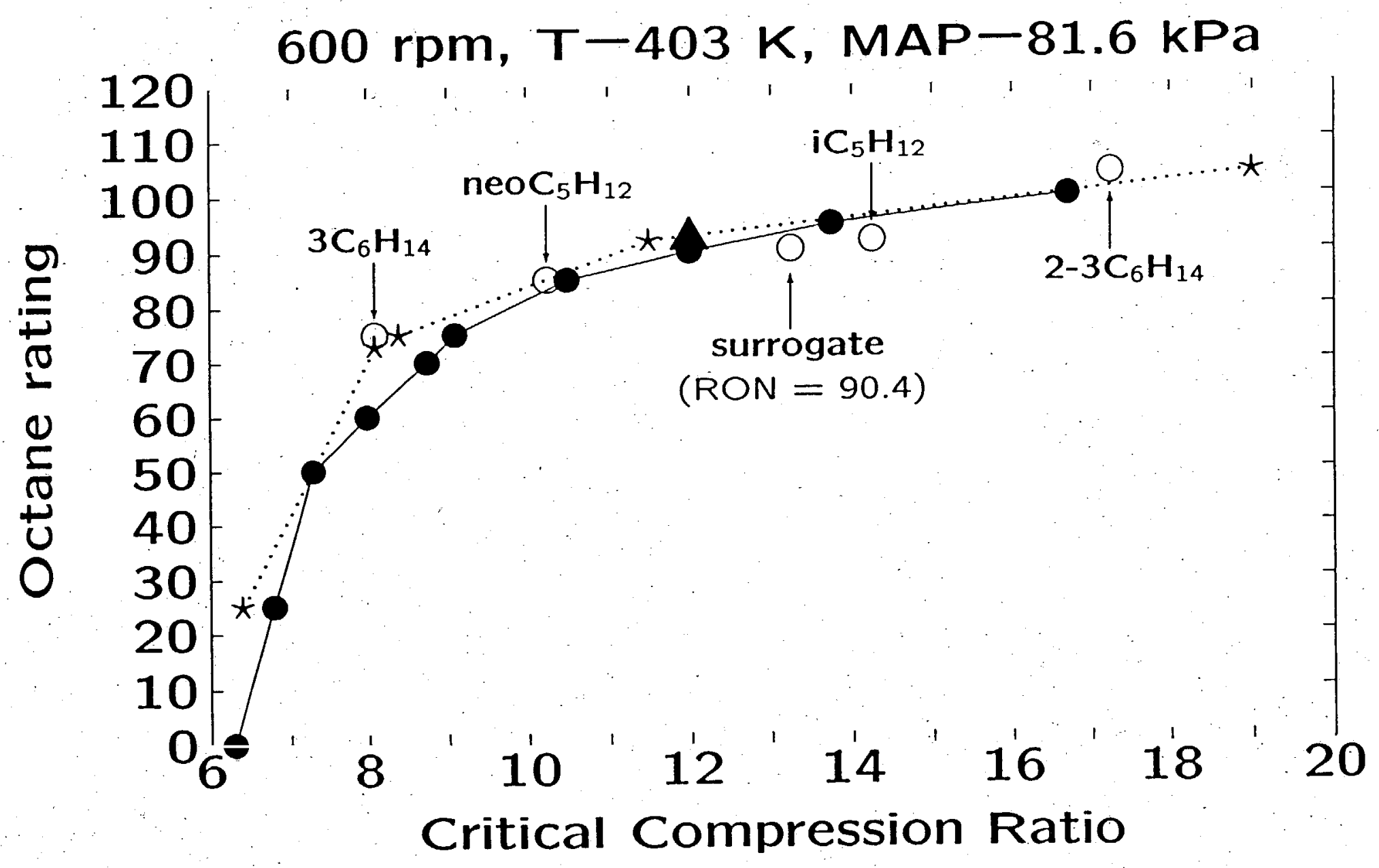




\section{Temperatures}

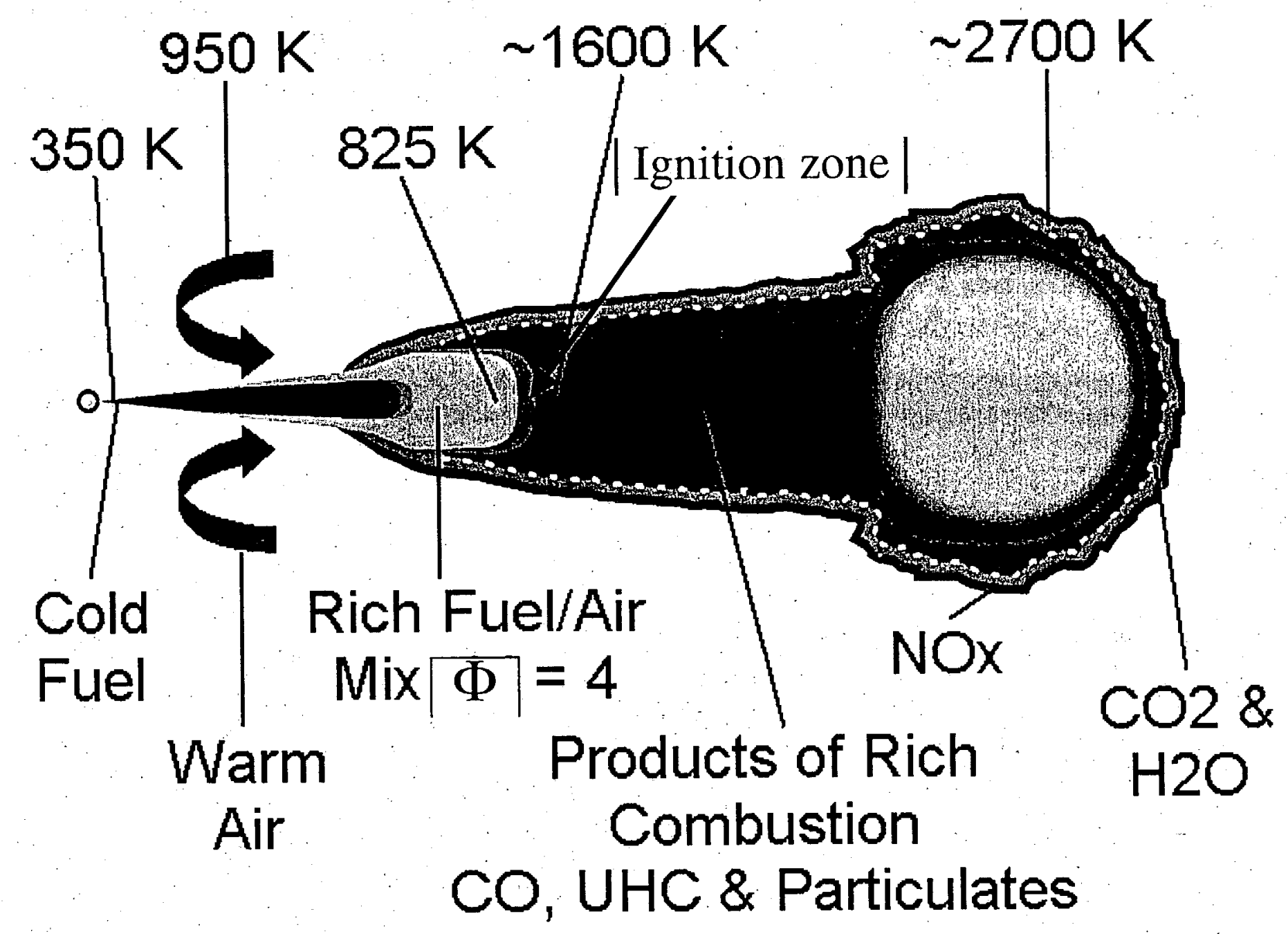

Chemistry 


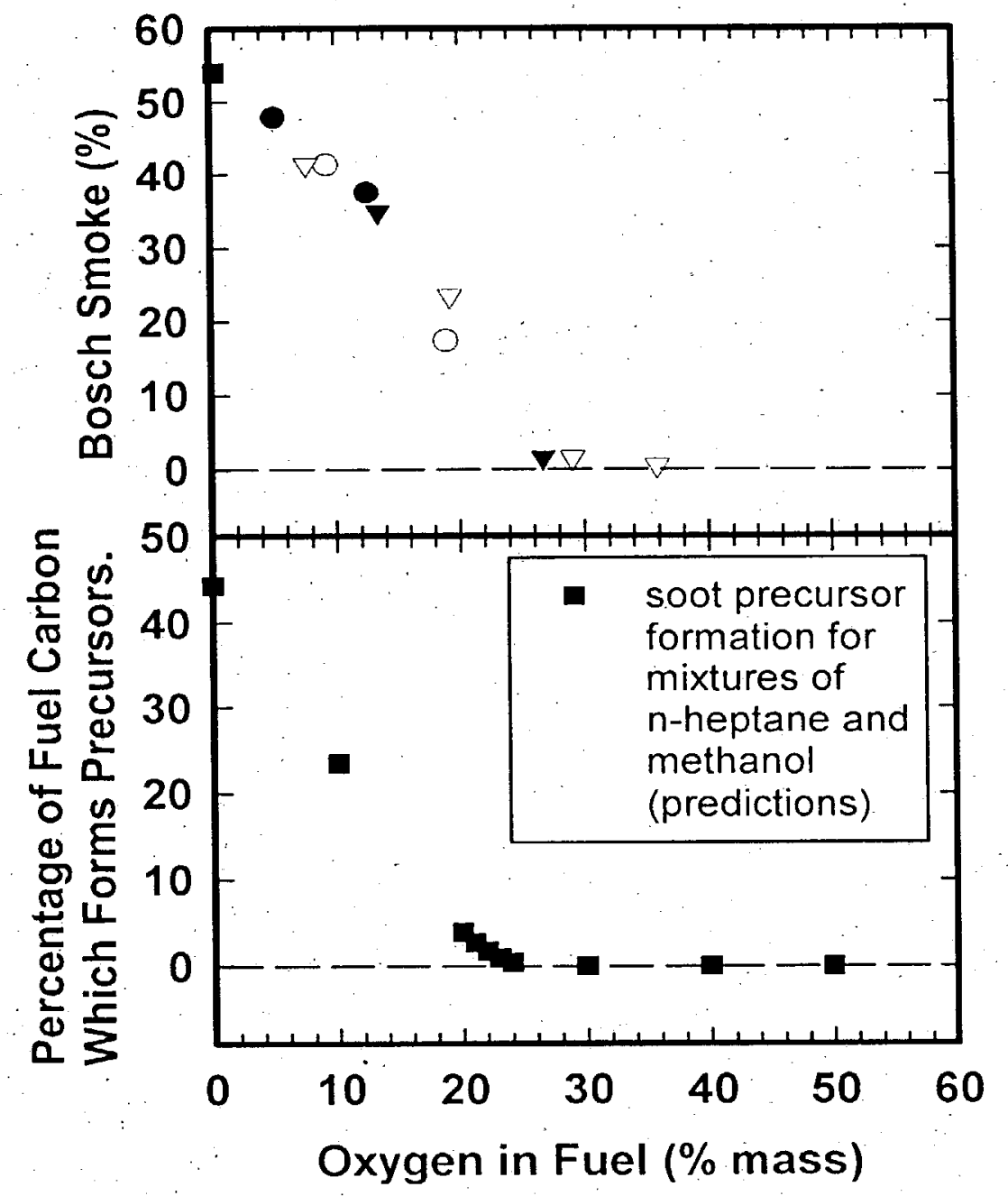




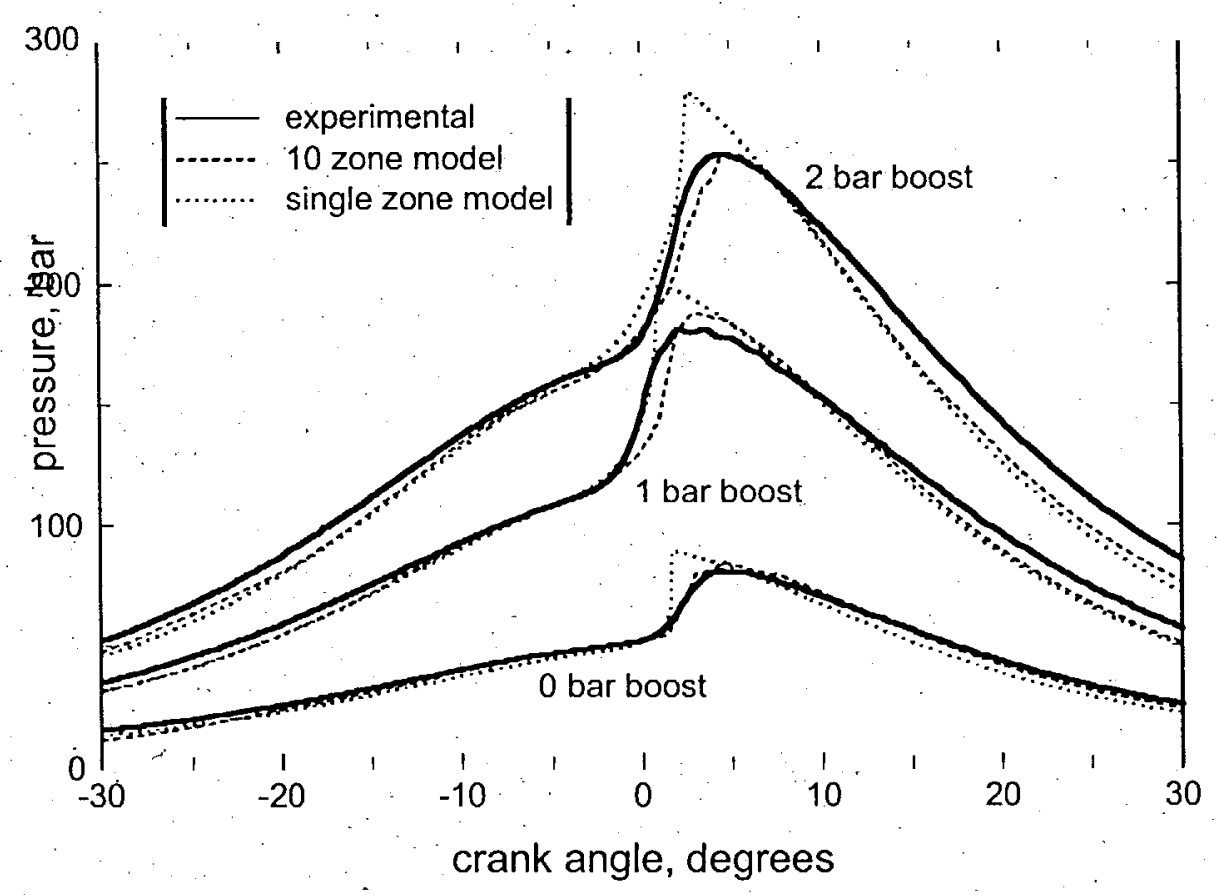




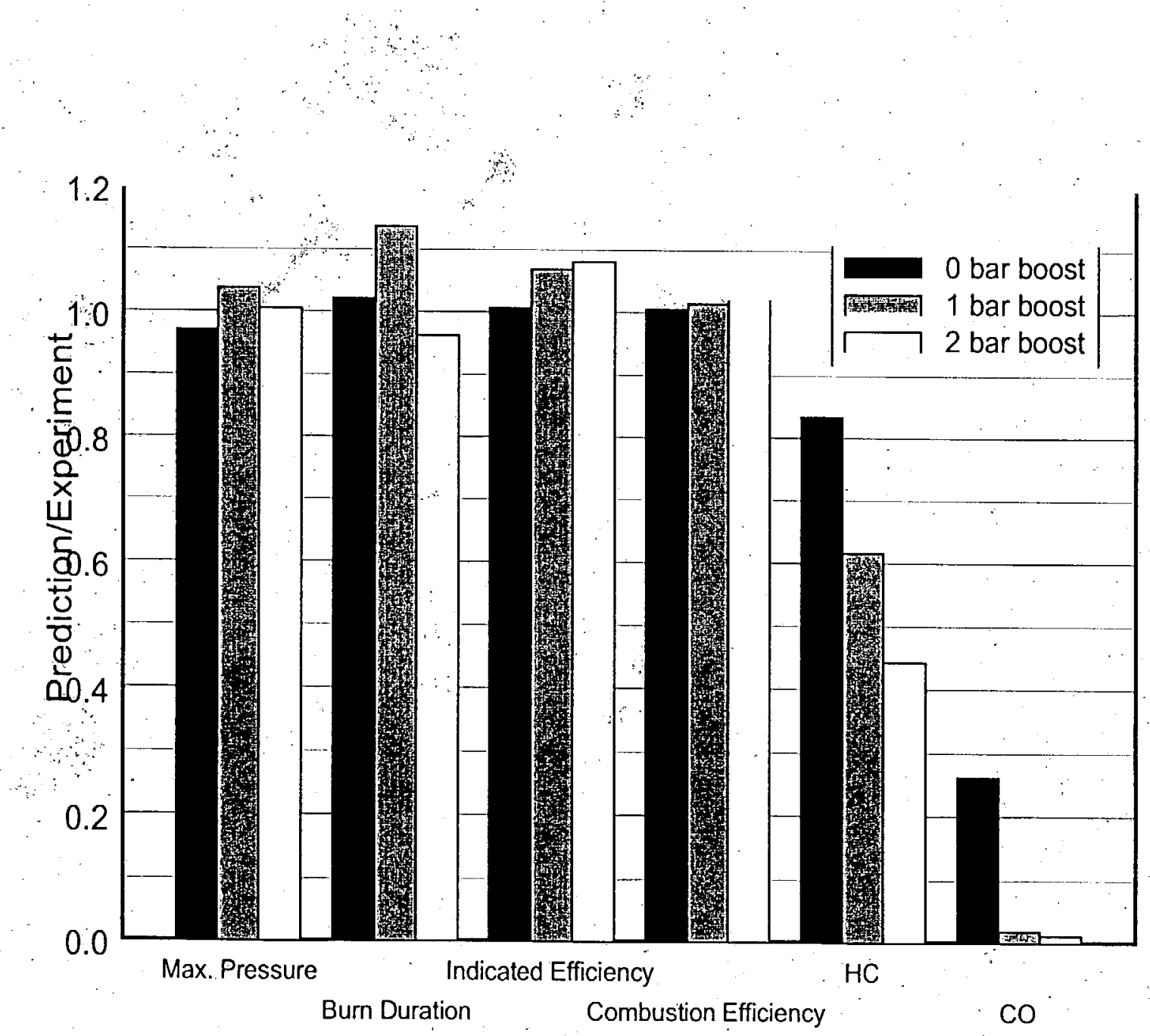




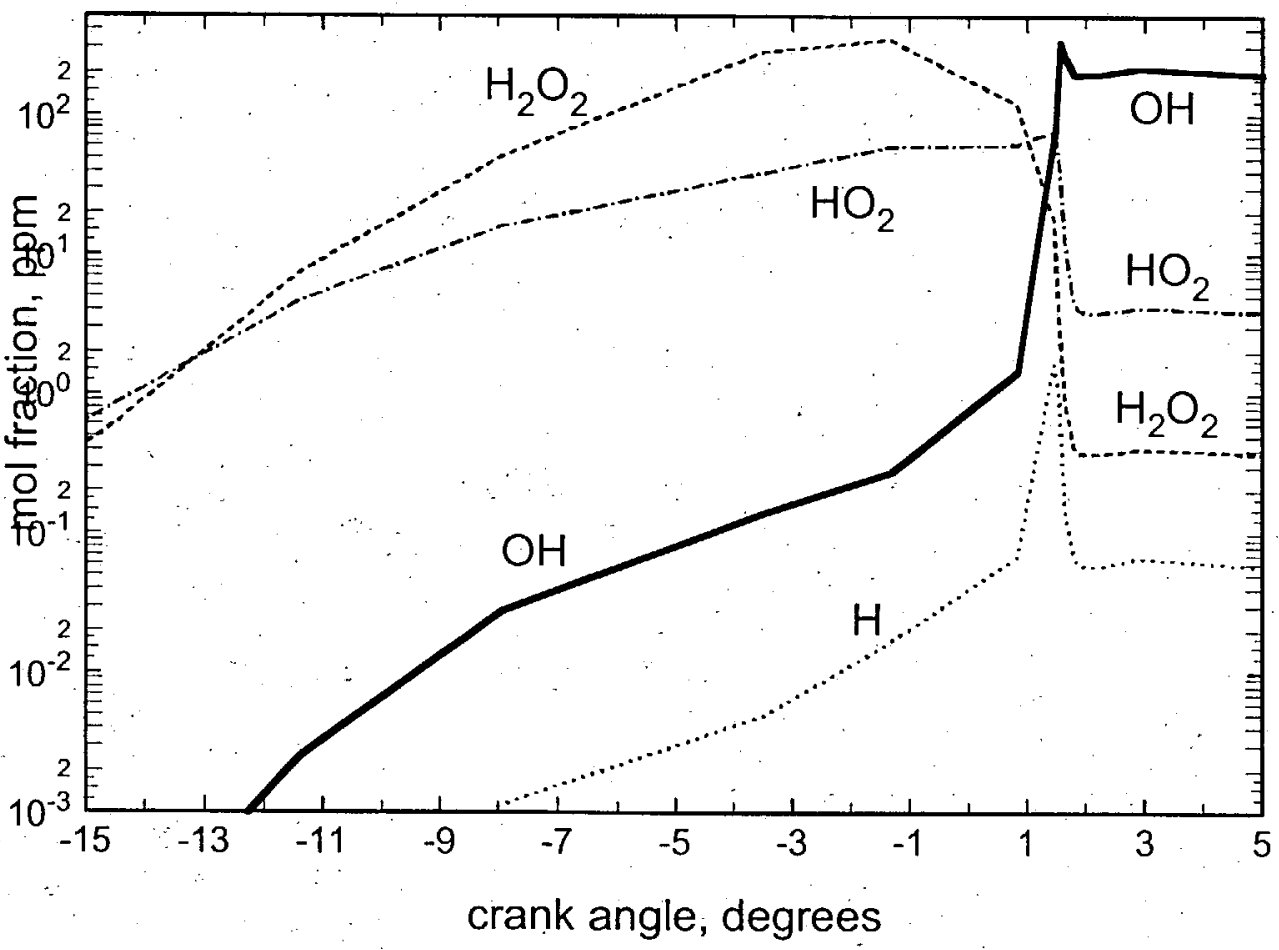

